\title{
Genetic, environmental and stochastic factors in monozygotic twin discordance with a focus on epigenetic differences
}

\author{
Witold Czyz ${ }^{1,2}$, Julia M Morahan ${ }^{1,2}$, George C Ebers ${ }^{1,2}$ and Sreeram V Ramagopalan ${ }^{1,2,3,4^{*}}$
}

\begin{abstract}
Genetic-epidemiological studies on monozygotic (MZ) twins have been used for decades to tease out the relative contributions of genes and the environment to a trait. Phenotypic discordance in $M Z$ twins has traditionally been ascribed to non-shared environmental factors acting after birth, however recent data indicate that this explanation is far too simple. In this paper, we review other reasons for discordance, including differences in the in utero environment, genetic mosaicism, and stochastic factors, focusing particularly on epigenetic discordance. Epigenetic differences are gaining increasing recognition. Although it is clear that in specific cases epigenetic alterations provide a causal factor in disease etiology, the overall significance of epigenetics in twin discordance remains unclear. It is also challenging to determine the causality and relative contributions of environmental, genetic, and stochastic factors to epigenetic variability. Epigenomic profiling studies have recently shed more light on the dynamics of temporal methylation change and methylome heritability, yet have not given a definite answer regarding their relevance to disease, because of limitations in establishing causality. Here, we explore the subject of epigenetics as another component in human phenotypic variability and its links to disease focusing particularly on evidence from MZ twin studies.

Keywords: Twins, Discordance, Epigenetics, Heritability, Environment
\end{abstract}

\footnotetext{
* Correspondence: s.ramagopalan@qmul.ac.uk

${ }^{1}$ Wellcome Trust Centre for Human Genetics, University of Oxford, Oxford, UK
}

Full list of author information is available at the end of the article

\section{Phenotypic variability and discordance}

The extent to which phenotypic traits are heritable has been a subject of scientific interest, at least since Galton's classic twin study design [1]. Twins offer a unique means to study inheritance. Monozygotic (MZ) twins arise from a single zygote, and have always been thought to inherit identical genomic sequences [1], whereas dizygotic (DZ) twins arise from two different zygotes and, just like siblings, share on average $50 \%$ identity in their genomic sequence. To assess the relative contribution of genes to a trait, comparisons are made between $\mathrm{MZ}$ and $\mathrm{DZ}$ twin concordance, with a greater $\mathrm{MZ}$ than $\mathrm{DZ}$ concordance rate implicating a role for genetics in determining the trait [1]. Phenotypic discordance between MZ twins has traditionally been ascribed to non-shared environmental exposures [2]; however, recent research highlights this as being too simplified an explanation. In this review, we focus on potential sources of MZ discordance.

\section{In utero environment and discordance}

There is a range of early environmental factors that need to be considered as potential explanations for MZ twin discordance. In some studies, similar pre-natal and postnatal conditions, for example a shared in utero environment or upbringing in one family, have been thought to promote phenotypic concordance, in contrast to nonshared exposures $[2,3]$. However, the concept of nonshared environment has important practical limitations. It is difficult to unambiguously identify the distinct factors and explain their differential effects on phenotype [3]. For instance, although MZ twins share a single uterus in multifetal pregnancies, they do not necessarily share a common in utero environment. Twinning itself is thought to be a rare malformation and a stochastic event, although there exists evidence for familiality $[1,4,5]$. MZ twins occur in about 3.5 in 1000 pregnancies or 4 in 1000 live births [6,7]. Depending on the time of zygote splitting, MZ twins can be divided into four groups[1]. If the zygote splits 
within 3 days, the twins are dichorionic and diamniotic (DC DA) (18 to 36\% of all MZ births). If splitting occurs after the third but before the seventh day, the twins are monochorionic but diamniotic (60 to $80 \%$ of cases) $[1,8]$. If division occurs between days 7 and 14, the twins are monochorionic and monoamniotic (MC MA), which accounts for 2 to $4 \%$ of all MZ twins[8]. Conjoined twins arise when splitting happens after the days 13 or $14[1,8]$. All multifetal pregnancies are more prone to complications (such as fetal malnutrition, growth restriction, and premature birth), with a mortality rate six times higher than for singletons, and a shorter average duration of twin pregnancy (35 weeks) [4,9-17]. Intrauterine growth restriction (IUGR) is a common issue in twin pregnancies, affecting 12 to $47 \%$ of all twin pairs [18]. It often leads to discordance in birth weight [18-20], and has been linked with discordance for a range of phenotypes, including height, head circumference, intelligence, language comprehension and expression, fine motor performance, balance, coordination, and visual-motor perception [18,20,21].

The potential causes of IUGR include genetic predisposition, in utero crowding, uneven allocation of blastomeres, uneven blood supply, and placental dysfunction (for example, placental abruption, infarcts, stem vessel thrombosis, velamentous insertion of the cord, and single umbilical artery) $[18,19,21-23]$. Some of these events, such as unequal division of blastomeres or uneven vascularization of the placenta, can be considered as non-shared early exposures, which can be classified, depending on the adopted definition, as environmental or stochastic. IUGR is even more pronounced in MC twins, for whom differences in placental sharing and vascularization lead to occasional unequal blood and nutrient sharing, and, in about $15 \%$ of MC diamniotic pregnancies, result in twin-to-twin transfusion syndrome (TTTS) $[6,18,21]$. MC twins have a higher incidence of congenital heart disorders, and TTTS increases this risk even further [6]. However, even in the absence of TTTS, MC twins are seven times more likely to develop congenital heart disease, and this usually occurs in one twin only $[5-7,13,21,24]$. The higher risk nature of multiple pregnancies, their proclivity towards complications, and the twin-twin competition for maternal resources increases the probability of a skewed environment affecting the twins in utero $[25,26]$.

After birth, any non-shared environmental exposure, such as diet, smoking, toxin exposure and infection, may contribute towards twin discordance [2,3,22,27-31]. Moreover, early phenotypic differences arising in twins could potentially cause shared exposures to have different effects, leading to dissimilarity between the twins.

\section{De novo mutations and genetic mosaicism}

It has been assumed that MZ twins are genetically identical, but a wealth of data are accumulating to show that this is not necessarily the case. Mosaicism for de novo mutations, retrotranspositions, indels, duplications, and chromosomal rearrangements may play a role in $\mathrm{MZ}$ twin discordance [32-44]. The rate for de novo base substitutions has been estimated at about $10^{-8}$ per base pair per generation, making some genetic differences between adult twins likely [45]. Postzygotic point mutations have been found to be the source of MZ twin discordance in oral-facial-digital syndrome type 1, Joubert syndrome, Van der Woude syndrome, Darier's disease, and neurofibromatosis type 1 while mosaicism for chromosomal abnormalities has been implicated in discordance for conditions such as Turner syndrome, trisomy 21 , trisomy 13 , skin pigmentation, and sex phenotypes [46-51]. Postzygotic karyotypic mosaicism caused by faulty mitotic division has also been reported in cases of Ulrich-Turner syndrome [22].

Copy number variants (CNVs), which account for a major portion of the genome, are strongly polymorphic and relatively unstable, with mutation rates 100 to 10000 times higher than those for single base substitutions[52]. Phenotypic discordance in MZ twins may in part be caused by de novo mutations of CNVs and CNV mosaicism $[32,34,36,53]$. Indeed, it has been indicated that de novo CNVs may occur at a rate of $10 \%$ per twinning event; however, studies have so far failed to link CNV mosaicism to any specific case of phenotypic discordance in MZ twins [40,54-56].

Additionally, unequal exchange of cells during gestation might potentially lead to discordant fetomaternal microchimerism [22].

\section{Developmental noise and stochasticity}

Some variation is inevitable as a result of transcriptional or translational stochasticity, entailed by the random movements of molecules and the complexity of their interactions [57-63]. It should be expected that such noise can lead to markedly different effects under identical environmental conditions [64]. The effect of developmental stochasticity might amass in a drift-like fashion, and thus be more relevant to discordance in complex polygenic traits such as height or weight, which develop over long periods [58]. Stochastic events such as unequal division of the inner mass cells during twinning, or unequal allocation of the developmental markers or precursor cells to different somatic lineages, have been reported as potential sources of discordance in MZ twins [5,37]. Certain cases of twin discordance might potentially be stochastic in origin, however because the causal mechanisms are not thoroughly understood, it is difficult to separate these from environmental effects and gene-environment interactions. Examples include discordance for eye or hair colour and fingerprint profiles, cases of mirror twinning (affecting up to $25 \%$ of MZ twins), and major malformations [22]. 
Certain cases of differential allelic expression (DAE), which result in random monoallelic gene expression, arising as a result of $\mathrm{X}$-inactivation or allelic exclusion in olfactory and pheromone receptor genes, can constitute a mechanism for stochastically driven phenotypic discordance in MZ twins [22,65-70]. Although DAE has also been estimated to affect about $50 \%$ of autosomal genes in $\mathrm{B}$-cells, the evidence from MZ twins indicates that the overall degree of DAE is to a certain extent under genetic control. with an estimated $30 \%$ of the affected genes showing significant correlation between co-twins [71]. The precise estimates of DAE and its concordance in MZ twins vary. A comprehensive whole genome expression experiment conducted by Baranzini et al. indicated that only $1.9 \%$ of heterozygous coding loci showed significant evidence for DAE, but out of these, 57\% were concordant between the co-twins, still leaving room for stochastic effects [72]; however, their findings were based on a single MZ twin pair [72].

\section{Epigenetics}

Epigenetics was initially a term coined by developmental biologists, and had no immediate link to the issues of epidemiology and heredity $[73,74]$. Rather, the term described the way in which gene-environment and genegene interactions shape a phenotype during development. The concept was developed as an argument for a complex relation between genes and phenotype. Today, epigenetics is used to describe alterations in genomic function, mainly mitotically heritable changes in gene expression that occur through chemical modifications to the structure of chromatin without altering the DNA sequence [2,27,73-76]. There is some limited evidence for transgenerational inheritance of epigenetic changes in mammals, but the scope and mechanisms are under study $[3,77]$.

Cytosine methylation is one of the most well studied epigenetic alterations found in vertebrates [27,73-76]. It occurs at approximately 4 to $6 \%$ of the genomic cytosine residues, depending on the cell type [78]. DNA methylation typically occurs in the context of CpG dinucleotides, although this depends on cell type. In fetal fibroblasts, 99.98\% of methylated cytosines are located in CpG dinucleotides [78]. By contrast, for embryonic stem cells the proportion reaches about $75 \%$, which highlights the importance of non-CG methylation for gene expression in pluripotent stem cells. Cytosine methylation is mediated by a family of proteins called DNA methyltransferases $[73,75,79]$. This form of modification is generally associated with transcriptional inactivation. It both physically prevents transcription factors from binding to the DNA, and can also recruit additional factors, such as methylCpG binding domain proteins, which can promote repressive histone modifications $[27,73,75,76]$. However some CpGs remain unmethylated [73]. The precise mechanism by which the differential methylation of $\mathrm{CpG}$ dinucleotides occurs is unknown [73]. Recently, hydroxymethylation of cytosines has been discovered, but its biological significance is not yet known.

The second category of epigenetic modifications characteristic of all eukaryotes is the category of covalent alterations to histone proteins $[27,73-76]$. These affect the $\mathrm{N}$-terminal histone tails and, depending on the position and the type of alteration, can either repress or promote active chromatin conformation [73,76]. The two most important types are acetylation and methylation [76]. The various types of histone modifications have led to the hypothesis of an epigenetic histone code that moderates transcription in response to developmental cues and the environment [76]. Cytosine methylation, histone modifications, and other types of chromatin remodeling all act together in concert, and either reinforce or disable each other through feedback loops [73].

There is substantial evidence in support of epigenetic components in defining human phenotypic variation. Most of this evidence comes from studies of defects in genetic imprinting: an asymmetric, sex-dependent epigenetic moderation of paternal versus maternal gene expression that manifests in monoallelic expression [75]. For imprinted genes, epigenetic modifications are set anew in the germline in each generation, according to sex [75]. Occasional abnormal cytosine methylation can result in epigenetic alterations called epimutations, which just like DNA mutations, can deactivate the gene or cause both copies of the imprinted gene to be transcriptionally active [75]. Such alterations can be divided broadly into three different categories, depending on their origin. Some epimutations have a direct genetic cause, and are secondary to a DNA mutation in cis or in trans; for instance mutations to imprinting centers. Other epimutations are primary, with no sequence alteration $[75,80]$ (Figure 1). This latter category can be further divided into stochastic epimutations, caused by the inherently error-susceptible molecular machinery, and environmental epimutations, which are caused by environmental factors. This distinction can be arbitrary because the environment can potentially cause stochastic epimutations. The ratio between primary and secondary epimutations is not well defined. There might also exist an intermediate type of 'facilitated epimutations', that is, when the likelihood of a stochastic epimutation at certain locus is increased by genetic determinants[80]. Theoretically, any gene can be targeted by epimutation, giving rise to abnormal conditions; however, imprinted genes represent a more sensitive category on account of their monoallelic expression.

If differences in DNA methylation can be sufficient to cross the boundary between normal and disease phenotype in imprinted, monoallelically expressed genes, then it is also probable that epimutations might affect expression 


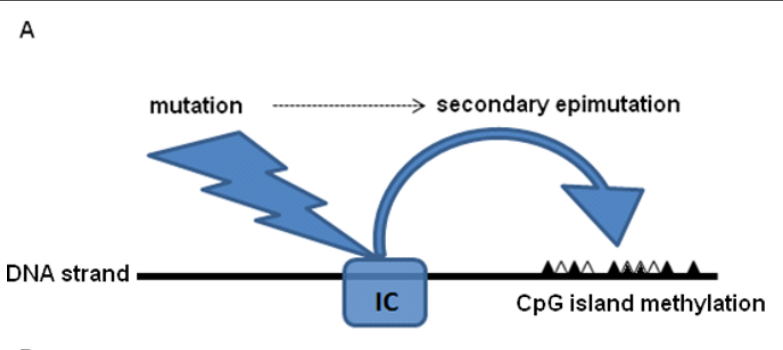

B

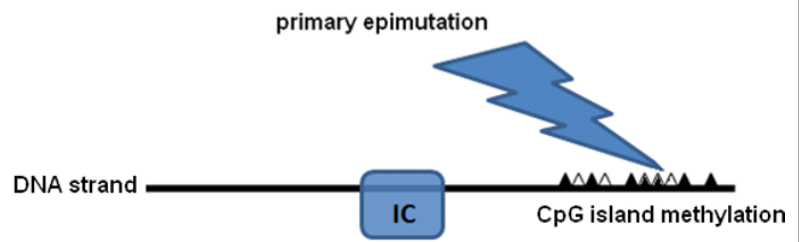

Figure 1 (A) The mechanism of a secondary epimutation. A DNA alteration at an imprinting center (IC) indirectly influences and alters the methylation pattern (black and white triangles) at another locus, which could be in cis or in trans. (B) In primary epimutation, the external stimulus (whether environmental or stochastic) directly alters the methylation.

of any pair of genes. Of course, with genes that are expressed in a normal biallelic manner, the effects would presumably be less severe. Consequently, as the complexity and polygenicity of a trait increases, the effect of an epimutation would most probably decrease. However, each potential target for an epimutation would increase the variability of that trait, and because epimutations may arise during development, it follows that organisms can be subject to epigenetic variegation and therefore ought to be heterogeneous for their epigenomes $[42,81]$. Thus epigenetic mosaicism between twins could be yet another source of phenotypic variation. Indeed, mosaicism in epigenetic alterations has been described in MZ twins, and its relevance to phenotype, particularly disease, is the subject of current studies [82].

The significance of the environment and genes in driving epigenetic changes is a subject of debate, with some authors claiming that epimutations might be stochastic in nature and offer an alternative, non-heritable, and nonenvironmental explanation for phenotypic variability $[2,72,73,83]$. The key argument rests on the arbitrary assumption that the random character of de novo faults in DNA methylation, whose fidelity is estimated to be at the level of 97 to $99.9 \%$ in cell culture, but lower in vivo, cannot be ascribed to heritable genetic predispositions or to the environment $[2,73]$. Thus, the concept of stochastic epimutations as the third source of variation in opposition to genetic and environmental effects has important limitations because it is not evident that the random faults in methylation maintenance are not themselves genetically determined (in a similar way to DAE), or of environmental origin.

Studies using methylome profiling, locally or globally, offer a direct method of evaluating the specific contribution of epigenetics to a phenotype. Some of the main questions raised by these studies' authors concern the nature of this contribution, namely the ratio between hereditary, environmentally triggered, and (potentially independent of the former) stochastic changes. The extent of epigenetic changes and epigenome heritability is disputable. A thorough cross-sectional study of epigenetic profiles in the lymphocytes of $80 \mathrm{MZ}$ twins, aged between 3 and 74 years, revealed significantly greater discordance in the older participants [29]. By estimating total genomic 5-methyl-cytosine content and histone $\mathrm{H} 3$ and $\mathrm{H} 4$ acetylation, $65 \%$ of the twins were found to have almost identical epigenomes, while the remaining 35\% were found to be variably discordant. Both the histone acetylation and DNA methylation profiles of twins become progressively discordant with age, different lifestyles, and different medical history. More importantly, the same pattern of epigenetic discordance was seen with buccal epithelial cells, intraabdominal fat cells, and skeletal muscle cells. Fraga et al. (2005) propose that the epigenome is strongly heritable at birth, but epimutations arise and accumulate throughout a lifetime, and their origin arises as a result of a combination of external environmental factors and internal 'epigenetic drift' arising from defects in methylation[29]. Although such maintenance defects have been claimed by others to represent 'endogenous, stochastic mechanisms, independent of environmental perturbations [84], Fraga et al. do not exclude the notion they might be environmentally triggered as well [29]. In a similar study, Kaminsky et al. (2009) used CpG island microarrays to screen about 6000 loci (as compared with 1800 loci investigated by Fraga et al.), in a cohort of $114 \mathrm{MZ}$ and $80 \mathrm{DZ}$ twins, in search of methylation differences [85]. Some discordance was found in white blood cells and replicated in buccal and gut tissue. Estimates based on $20 \mathrm{MZ}$ and $20 \mathrm{DZ}$ pairs indicated that methylation heritability was very low in white blood cells, but rose in buccal tissue (findings based on $19 \mathrm{MZ}$ and 20 DZ pairs), and was significantly greater when dichorionic twins only were considered. The fact that the buccal epithelial tissues of MC MZ twins were significantly more discordant than those of DC twins signals chorionicity as an important environmental factor influencing the epigenome, and this was not taken into account in the study of Fraga et al. The sample was not stratified according to age, which precludes inferences regarding early discordance. The findings of Kaminsky et al. (2009) may suggest that late twinning can predispose to skewed environmental conditions and to more discordant epigenetic profiles. Kaminsky et al. oppose stochasticity to environmentally 
induced epigenetic differentiation, favoring the former explanation as the more important in phenotypic discordance of MZ twins [85].

The study of Fraga et al. (2005) stressed the significance of age in DNA methylation discordance in twins. The youngest twin pair studied by the authors had identical methylation levels [29]. In 2010, Saffery et al. sampled four different tissue types from $56 \mathrm{MZ}$ and $35 \mathrm{DZ}$ twins pairs at birth, and analysed them for $\mathrm{CpG}$ methylation at four differentially methylated regions (DMRs) associated with the IGF2/H19 locus [86]. Within the MZ pairs, the absolute methylation difference for all DMRs and tissues was generally small and ranged between 3 and 4\%; however, the difference varied depending on the tissue type and specific $\mathrm{CpG}$ tested. An effect of chorionicity was confirmed. The largely similar epigenetic profiles at birth would support the study of Fraga et al., but conclusions are limited by the investigation of just four genetic regions. Longitudinal studies of $\mathrm{CpG}$ methylation in $\mathrm{MZ}$ twin cohorts, optimally sampled at birth first, are better means to estimate the levels of epigenetic discordance and make inferences upon its nature. In one of the first longitudinal twin methylation studies, Wong et al. attempted to address the issue of epigenetic heritability and stochastic versus environmental epigenetic change [87]. They examined $46 \mathrm{MZ}$ and $45 \mathrm{DZ}$ twin pairs for methylation at three chosen loci relevant to psychology, first at the age of 5 years and then at the age of 10 years. They found variable discordance in all pairs. Not all loci were equally prone to temporal epigenetic change, although alterations were seen for all three genes. By comparing $\mathrm{MZ}$ to $\mathrm{DZ}$ concordance rates, no significant differences were detected, and the authors concluded that alterations - both shared (indicated by high concordance) and non-shared - were weakly heritable, and thus predominantly attributable to the environment. Interestingly, despite the low heritability, the intraclass correlation coefficients (ICC) of MZ twins remained stable or increased. This might be a consequence of the narrow locus-specific scope of the study [87]. Wong et al. did not give any explanation for the phenomenon and concluded that the epigenome is dynamic and subject to changes and environmental influence. It can differ between MZ twins even in early childhood and, depending on the locus, both non-shared and common familial environments can significantly affect its methylation profile. However, Wong et al. acknowledge that when ICC and heritability is low, indicating little familial environment and genetic contribution, stochastic epimutations can provide an alternative explanation for the discordance. Further confirmation of those conclusions are required.

The most recent epigenomic study, by investigated methylation levels in a cohort of $230 \mathrm{MZ}$ twin pairs (although 219 pairs appear in the analysis) whose age ranged from 18 to 89 years, both globally and across a panel of nine chosen loci that have been implicated in agerelated diseases and epigenetic regulation [88]. The authors adopted a cross-sectional approach, but a subset of 38 twins was re-assayed longitudinally after a 10-year interval. Although a small intra-pair discordance for global methylation was seen, older pairs were found to be twice as discordant as the younger twins [88]. This trend also held true for the disease-related loci, with older twins displaying discordance that was 1.4 to 2.7 -fold greater, and a variation increasing proportionately with age (with very weak effects of changing cellular heterogeneity) [88]. Both global and locus-specific temporal increase in methylation discordance was confirmed by a longitudinal follow-up. The overall absolute global methylation differences between the twins were nonetheless small $(1.1 \%$ in younger and $2.1 \%$ in older pairs). The results seem to confirm the earlier findings by Fraga et al. (2005) and suggest that discordance increases progressively with age [88]. The study points to the importance of unique individual environment behind the discordance, but explains the trend with both the influence of stochastic and environmental factors, acknowledging the difficulty in separating their effects from each other, and stressing that non-shared environmental exposures may also drive stochastic epigenetic discordance [88]. Table 1 sums up the main methylomic stability and discordance studies conducted in MZ twins.

Together, these findings suggest that methylation patterns can be to a large extent genetically determined and heritable, yet do not remain stable over a person's lifetime. Variable degrees of epigenetic discordance can be seen in MZ twins, and it is evident that sample size, age, tissue type and $\mathrm{CpG}$ island selection can all significantly influence its estimates. There is substantial locus-to-locus and inter-individual variation in temporal methylation dynamics. To date, there is conflicting evidence on early epigenetic discordance in MZ twins, but age should be a crucial factor in all future studies of methylome changes. Chorionicity seems to be an important factor altering discordance and heritability estimates, therefore studies investigating methylome concordance in twins should also take this into account, although this information is often lacking. One potential problem that can affect findings in longitudinal studies is resampling from epigenetically different cellular subpopulations [87]. The environmental influence on the epigenome is relevant, and global epigenome studies in human MZ twins alone cannot resolve the sources of epigenetic discordance. Because the intrauterine environment, post-natal shared and non-shared environmental factors, and sequence polymorphisms acting in cis and trans can all be partly responsible for the methylation discordance, evaluating the significance of the intrinsic, 
Table 1 Studies of CpG methylation discordance in monozygotic (MZ) twins

\begin{tabular}{|c|c|c|c|c|c|}
\hline Study & Type & Method & Tissue & MZ pairs, $n$ & Conclusion \\
\hline $\begin{array}{l}\text { Fraga et } \\
\text { al. [29] }\end{array}$ & $\begin{array}{l}\text { Cross-sectional, } \\
\text { age-stratified }\end{array}$ & $\begin{array}{l}\text { High-performance capillary } \\
\text { electrophoresis of total methyl- } \\
\text { cytosine content }\end{array}$ & $\begin{array}{l}\text { Peripheral lymphocytes; } \\
\text { buccal epithelial cells; } \\
\text { muscle biopsy; adipose } \\
\text { tissue }\end{array}$ & 40 & $\begin{array}{l}\text { Young MZ twins are nearly identical } \\
\text { epigenetically; discordance } \\
\text { progresses with age, mediated by a } \\
\text { combination of external and/or } \\
\text { internal factors. }\end{array}$ \\
\hline $\begin{array}{l}\text { Kaminsky } \\
\text { et al. [85] }\end{array}$ & Cross-sectional & $\begin{array}{c}\text { Human } 12 \mathrm{~K} \mathrm{CpG} \text { island } \\
\text { microarrays }\end{array}$ & $\begin{array}{l}\text { White blood cells, buccal } \\
\text { epithelial cells, rectal biopsy }\end{array}$ & $57^{1}$ & $\begin{array}{l}\text { Methylation discordance in MZ twins } \\
\text { confirmed; monochorionic MZ twins } \\
\text { significantly more discordant than } \\
\text { dichorionic MZ twins. Epigenetic drift } \\
\text { suggested as the main cause of } \\
\text { discordance }\end{array}$ \\
\hline $\begin{array}{l}\text { Saffery et } \\
\text { al. [86] }\end{array}$ & $\begin{array}{l}\text { Cross-sectional, } \\
\text { taken at birth }\end{array}$ & Bis-seq (IGF2/H19) & $\begin{array}{l}\text { Cord blood, mononuclear } \\
\text { cells, buccal epithelial cells, } \\
\text { placental cells, umbilical } \\
\text { vein cells, endothelial cells }\end{array}$ & 56 & $\begin{array}{c}\text { CpG methylation discordance can } \\
\text { arise in newborn twins by } \\
\text { combination of environmental and/or } \\
\text { stochastic factors acting in utero and } \\
\text { varies depending on the type of the } \\
\text { tissue. }\end{array}$ \\
\hline $\begin{array}{l}\text { Wong et } \\
\text { al. [87] }\end{array}$ & $\begin{array}{l}\text { Longitudinal, } \\
\text { with single 5- } \\
\text { year interval }\end{array}$ & $\begin{array}{c}\text { High-throughput mass } \\
\text { spectrometry (DRD4, SERT, } \\
\text { MAOA) }\end{array}$ & Buccal cells, epithelial cells & 46 & $\begin{array}{l}\text { CpG methylation discordance is } \\
\text { present in early childhood and } \\
\text { susceptibility to epigenetic change is } \\
\text { highly locus-specific. Environmental } \\
\text { influence is the main cause of } \\
\text { discordance, with various loci having } \\
\text { differential susceptibility to shared } \\
\text { and non-shared exposures }\end{array}$ \\
\hline $\begin{array}{l}\text { Talens et } \\
\text { al. [88] }\end{array}$ & $\begin{array}{l}\text { Cross-sectional } \\
\text { and } \\
\text { longitudinal } \\
\text { with single 10- } \\
\text { year interval }\end{array}$ & $\begin{array}{l}\text { High-throughput mass } \\
\text { spectrometry; global methylation } \\
\text { and selected loci (IGF2, LEP, CRH, } \\
\text { ABCA1, INS, KCNQ1OT1, GNASAS) }\end{array}$ & Whole blood & 230 & $\begin{array}{c}\text { Global and locus-specific methylation } \\
\text { increases gradually with age, owing } \\
\text { to unique environmental and } \\
\text { stochastic factors }\end{array}$ \\
\hline
\end{tabular}

Abbreviations: $M Z$, monozygotic; Bis-seq, bisulfite sequencing

${ }^{1}$ Not all pairs were used for each estimate in the study

stochastic epigenetic drift poses a methodological obstacle that is difficult to surmount $[4,29,73,86,87,89,90]$. Estimating the exact proportion of stochastically determined differences will require a deeper knowledge of the ways in which the non-shared environment shapes the methylome and the specific mechanisms responsible for the drift [29]. These may be difficult to investigate in humans.

\section{Methylation studies and human disease}

A number of studies have investigated methylation differences in MZ twins in relation to disease or different phenotypic conditions (Table 2). Initially, studies utilized bisulfite conversion combined with sequencing of preselected candidate loci. In some of the very first twin methylation studies Petronis et al. found differences in the CpG methylation of a regulatory sequence of the dopamine D2 receptor, and this was greater in a schizophrenia-discordant pair than in a concordant one [91]. Another early study using bisulfite sequencing found methylation discordance at two regions of the COMT gene promoter in a sample of six MZ twin pairs, all discordant for birth weight [92]. Oates et al. (2006) used bisulfite sequencing of the AXIN1 promoter in a MZ pair discordant for caudal duplication anomaly [93].
More recently, a survey of $\mathrm{CpG}$ methylation of six chosen tumor-suppressor genes (ATM, BRCA1, BRCA2, $M L H 1, R A D 51 C$ and TP53) in a single MZ twin pair discordant for childhood leukemia and secondary thyroid carcinoma, identified increased BRCA2 methylation [82]. The proband had a significantly more methylated promoter than the healthy co-twin. The main limitations of these studies are the small sample sizes and narrow scope, limiting the number of potential associations to be found.

With the advance of microarray and next-generation sequencing technology, it became possible to study methylation changes on a genome-wide scale. In a study of discordant risk-taking attitudes in a single MZ twin pair, Kaminsky et al (2007) looked at CpG methylation of about 12,192 CpG loci and found differences in methylation of the DLX1 gene, implicated in stressresponse [94]. A methylation-sensitive-representational difference analysis study on a MZ pair discordant for bipolar disorder by Kuratomi et al. yielded four DMRs and one candidate gene, also confirmed to be differentially expressed [95]. Using an Illumina GoldenGate array, Javierre et al (2009) looked at methylation of $1505 \mathrm{CpG}$ sites in 807 gene promoters across five MZ 
Table 2 Methylation studies in monozygotic (MZ) twins discordant for personality and disease

\begin{tabular}{|c|c|c|c|c|c|}
\hline Study & Condition & Method & Tissue & $\begin{array}{l}\mathrm{MZ} \\
\text { pairs, } \mathrm{n}\end{array}$ & Results \\
\hline $\begin{array}{l}\text { Weksberg } \\
\text { et al. [83] }\end{array}$ & $\begin{array}{l}\text { Beckwith- } \\
\text { Wiedemann } \\
\text { syndrome }\end{array}$ & $\begin{array}{l}\text { Southern blotting with } \\
\text { DMR probes (H19, } \\
\text { KVDMRT, SNRP) }\end{array}$ & $\begin{array}{l}\text { Lymphocytes and } \\
\text { fibroblasts }\end{array}$ & 10 & Loss of methylation at KvDMR1 in all probands \\
\hline $\begin{array}{l}\text { Petronis } \\
\text { et al. [91] } \\
\end{array}$ & Schizophrenia & Bis-seq (DRD2) & Lymphocytes & 1 & Discordance confirmed \\
\hline $\begin{array}{l}\text { Mill et al. } \\
{[92]}\end{array}$ & $\begin{array}{l}\text { Attention deficit } \\
\text { hyperactivity } \\
\text { disorder }\end{array}$ & Bis-seq (COMT) & Buccal epithelial cells & 12 & 0.1 to $52.3 \%$ discordance \\
\hline $\begin{array}{l}\text { Oates et } \\
\text { al. [93] }\end{array}$ & Caudal duplication & Bis-seq (AXIN1) & PBMC & 1 & Discordance confirmed \\
\hline $\begin{array}{l}\text { Kuratomi } \\
\text { et al. [95] } \\
\end{array}$ & Bipolar disorder & MS-RDA & $\begin{array}{l}\text { Lymphoblastoid cell } \\
\text { lines }\end{array}$ & 1 & 4 DMRs, 1 candidate gene \\
\hline $\begin{array}{l}\text { Kaminsky } \\
\text { et al. [94] }\end{array}$ & $\begin{array}{l}\text { Risk-taking } \\
\text { behavior }\end{array}$ & MEDIP-chip & PBMC & 1 & 38 DMRs, 1 candidate gene \\
\hline $\begin{array}{l}\text { Mastroeni } \\
\text { et al. [32] }\end{array}$ & Alzheimer disease & Immunohistochemistry & Temporal neocortex & 1 & Discordance confirmed \\
\hline $\begin{array}{l}\text { Javierre } \\
\text { et al. [96] }\end{array}$ & $\begin{array}{l}\text { Systemic lupus } \\
\text { erythematosus }\end{array}$ & MEDIP-chip & White blood cells & 5 & 49 DMRs, 8 candidate genes \\
\hline $\begin{array}{l}\text { Wong } \\
\text { et al. [87] }\end{array}$ & $\begin{array}{l}\text { ADHD, depression, } \\
\text { antisocial behavior }\end{array}$ & $\begin{array}{l}\text { Quantitative high- } \\
\text { throughput mass } \\
\text { spectrometry (DRD4, SERT, } \\
\text { MAOA) }\end{array}$ & Buccal epithelial cells & 46 & Discordance confirmed \\
\hline $\begin{array}{l}\text { Baranzini } \\
\text { et al. [72] }\end{array}$ & Multiple sclerosis & RRBS & CD4+ lymphocytes & 3 & 2-178 DMRs, no candidate \\
\hline $\begin{array}{l}\text { Hu et al. } \\
\text { [98] }\end{array}$ & Autism & MEDIP-chip & $\begin{array}{l}\text { Lymphoblastoid cell } \\
\text { lines }\end{array}$ & 3 & 73 DMRs, 2 candidate genes \\
\hline $\begin{array}{l}\text { Tierling } \\
\text { et al. [118] }\end{array}$ & $\begin{array}{l}\text { Beckwith- } \\
\text { Wiedemann } \\
\text { syndrome }\end{array}$ & Bis-seq (11 DMR) & $\begin{array}{l}\text { Peripheral blood cells, } \\
\text { buccal epithelial cells, } \\
\text { skin fibroblasts, saliva }\end{array}$ & 1 & Hypomethylation at KvDMR1 \\
\hline $\begin{array}{l}\text { Harder } \\
\text { et al. [119] }\end{array}$ & Optic glioma & Bis-seq (NF1) & Leukocytes & 8 & Discordance confirmed \\
\hline $\begin{array}{l}\text { Souren } \\
\text { et al. [120] }\end{array}$ & $\mathrm{BMI}$ & Bis-seq & Saliva & 8 & $\begin{array}{l}\text { Small discordance identified, not correlated with } \\
\text { BMI discordance }\end{array}$ \\
\hline $\begin{array}{l}\text { Rakyan } \\
\text { et al. [90] }\end{array}$ & Type 1 diabetes & Illumina Array & CD14+ cells & $\begin{array}{l}15(+9 \\
\text { healthy } \\
\text { control) }\end{array}$ & 132 methylation variable positions \\
\hline $\begin{array}{l}\text { Dempster } \\
\text { et al. [99] }\end{array}$ & $\begin{array}{l}\text { Schizophrenia/ } \\
\text { Bipolar disorder }\end{array}$ & Illumina Array & Whole blood & 22 & $\begin{array}{l}\text { Disease-associated DMRs, including ST6GALNAC1 as } \\
\text { the top candidate }\end{array}$ \\
\hline $\begin{array}{l}\text { Galetzka } \\
\text { et al. [82] }\end{array}$ & $\begin{array}{l}\text { Childhood } \\
\text { leukemia/ } \\
\text { secondary thyroid } \\
\text { carcinoma }\end{array}$ & $\begin{array}{l}\text { Bis-seq (6 tumor } \\
\text { suppressors) }\end{array}$ & Skin fibroblasts & 1 & Increased BRCA1 methylation \\
\hline $\begin{array}{l}\text { Gervin } \\
\text { et al. [100] }\end{array}$ & Psoriasis & Illumina Array & CD4+ and CD8+ cells & 27 & $\begin{array}{l}\text { No significant methylation difference. Significant } \\
\text { correlation between some DMRs and psoriasis- } \\
\text { associated gene expression differences }\end{array}$ \\
\hline
\end{tabular}

Abbreviations: Bis-seq, bisulfite sequencing; BMI, body mass index; DMR, differentially methylated region; MS-RDA, Methylation-sensitive representational difference analysis; PBMC, peripheral blood mononuclear cell; RRBS, reduced representation bisulfite sequencing; MeDIP-chip, Methylated DNA

immunoprecipitation - chip

twins discordant for systemic lupus erythematosus (SLE), five twins discordant for rheumatoid arthritis (RA) and five twins discordant for dermatomyositis (DM), and discovered significant differences at 49 loci between the SLE-affected twins and their healthy co-twins, which were not seen in the RA and DM discordant twins [96]. The SLE cases had lower methylation levels and higher expression in several genes with immune functions. In a more recent analysis, Baranzini et al. used reduced representation bisulfite sequencing to investigate differences in methylation state of approximately 2 million CpG dinucleotides in three $\mathrm{MZ}$ twin pairs discordant for multiple sclerosis) [72]. The authors used high thresholds for methylation differences, which reduced the number of 
differentially methylated loci to 2,10 and 176 between the different twin pairs. The differences were inconsistent between the three twin pairs, leading the authors to conclude that methylation differences could not explain twin discordance. The study's small sample size and its heterogenous character (twins of Ashkenazi Jewish African American and European descent) constituted perhaps the greatest limitation reducing the power to detect significant methylation differences [97]. A recent analysis of methylation in three pairs of MZ twins discordant for autism using an $8.1 \mathrm{~K} \mathrm{CpG}$ microarray yielded 73 differently methylated CpG islands and two candidate genes [98]. The first genome-wide study using an Illumina $27 \mathrm{k}$ array (covering $\sim 27,000 \mathrm{CpG}$ sites) of MZ twin methylomes in schizophrenia and bipolar disorder in a cohort of 22 discordant pairs revealed a number of disease-associated DMRs, including GGN, SLC117A, SMUG1, SOX1 and TCF7L2, which had been implicated in a previous study [99]. Methylome profiling with the Illumina $27 \mathrm{k}$ array in a MZ twin cohort discordant for psoriasis failed to identify any significant DMRs, but did show that methylation correlated with the levels of expression at some disease-associated loci, including IL13, ALOX5AP, PTHLH and TNFSF11 [100]. A slightly different approach was adopted by Mastreoni et al., who used immunohistochemistry to investigate whole-tissue methylation [32]. Different methylation levels in temporal neocortex neuronal nuclei were found in two MZ twins discordant for Alzheimer disease, with hypomethylation in the affected twin [32].

Although genome-wide studies have enabled discovery of more DMRs, such studies are still in their infancy, and face a number of issues [101]. To date, most studies have investigated methylation in small samples of one to a dozen twin pairs; use of larger discordant MZ twin cohorts will increase the power to detect potentially causal DMRs. However, increasing the size of the twin sample might be challenging for rare diseases and study designs involving longitudinal sampling [101]. Improvements to study designs in the future will probably require sampling from multiple tissues, particularly those that might be relevant to disease, because variation in the epigenome varies significantly across different cell types, and tissue-specific epimutations may play more important roles than systemic epimutations. However, some tissues are not easily accessible, and sampling from different tissues might involve biopsy and post-mortem material [101]. This is an important limitation, and some of the recent studies assayed methylation differences in tissues that were not directly relevant to the disease investigated. Currently, the use of several technologies and platforms makes crosscomparisons difficult $[101,102]$. Comparisons between MZ and DZ and between MC and
DC twins should provide insights into the role of genetics and intrauterine environment in shaping epigenetic variation.

\section{Disease studies and causality}

The associations yielded by various methylation studies emphasize the need to develop methods that establish causality $[101,102]$. Traditionally, in genetic studies, this was achieved by demonstrating perfect co-segregation of putative causal alleles with affected individuals in families, as well as alterations to the expression or structure of the protein encoded by the allele $[103,104]$. In non-mendelian complex diseases with a significant environmental component and no clear-cut disease segregation, causality is mainly investigated through case-control association studies by sorting candidate genes using $P$-value thresholds that minimize false-positive errors, and optimally by replicating the results in independent cohorts [105-107]. Of course, owing to linkage disequilibrium, population stratification, type I and type II errors, or mere chance, association does not equate to causality until proven by functional work $[106,108]$. Proving causality is, just like the definition, ultimately always context-dependent, and there is no uniform agreement on what constitutes adequate evidence; however, most authors are clear that some physical, biological link ought to be established $[107,109-114]$. Epigenetic alterations at promoter sites should affect transcriptional activity [94,98]. However, the problem is that epigenetic differences could in fact be side-effects of disease or treatment. Studies investigating epigenetic changes are potentially prone to false conclusions as a result of reverse causation or confounding [115]. Because the nature of the epigenome is dynamic and most epimutations arise throughout a person's lifetime, the key to addressing causality might be in their timing [97]. A longitudinal approach assaying for epigenetic discordance at birth or in early infancy and resampling at regular intervals should produce a timeline for methylation changes, and help to sort the potentially causal alterations from the secondary, side-effect ones. Epigenetic differences identified in twins could be further investigated in longitudinal cohorts as part of a two-stage study design [115]. Ultimately, studies of disease-associated epigenetic changes should be followed up with the aim of establishing a link with biological function [115]. To date, only one longitudinal epigenome-wide study has been conducted, investigating single $\mathrm{CpG}$ methylation differences in a panel of MZ twins discordant for type 1 diabetes. [116] In this study, 132 methylation variable positions associated with disease status were discovered, some of which were replicated in an independent group of nine singletons affected with type 1 diabetes affected singletons prior to disease diagnosis. [116] 


\section{Conclusion}

The plausible assumption made by Galton[117] that twin discordance can be explained by differential environmental exposures after birth is no longer tenable. Genetics, the in utero environment, stochastity, and epigenetics can all potentially play a role in determining phenotypic discordance. The field of epigenetics is in its infancy. There is very strong evidence for the direct role and relevance of epigenetics in shaping human phenotypic variability. The role of the epigenome can be both as a mediator of genetic and environmental effects or as an independent stochastic factor. Currently, the significance of primary epimutations in twin discordance is unknown. Furthermore, it is not fully clear as to what extent the epigenome is heritable and whether monozygotic twins are epigenetically identical at birth. Further studies are required to address these important questions. Ultimately, longitudinal studies with repeated sampling may be required to fully understand the nature of monozygotic twin discordance.

\section{Funding}

This work was funded by the Wellcome Trust [090532/ Z/09/Z].

\section{List of Abbreviations}

BMI: body mass index; CNV: copy number variant; DA: diamniotic; DAE: differential allelic expression; DC: dichorionic; DM: dermatomyositis; DMR: differentially methylated region; DZ: dizygotic; UGR: intrauterine growth restriction; MA: monoamniotic; MC: monochorionic; MZ: monozygotic; RA: rheumatoid arthritis; RRBS: reduced representation bisulfite sequencing; SLE: systemic lupus erythematosus; TTTS: twin-to-twin transfusion syndrome.

\section{Authors' contributions}

WC and SVR designed the review and concepts, SVR and GCE were study supervisors, WC drafted the manuscript, JMM provided critical review of the manuscript. All authors read and approved the final manuscript.

\section{Competing interests}

The authors declare that they have no competing interests.

\section{Author details}

'Wellcome Trust Centre for Human Genetics, University of Oxford, Oxford, UK. ${ }^{2}$ Nuffield Department of Clinical Neurosciences (Clinical Neurology) University of Oxford, Oxford, UK. ${ }^{3}$ Blizard Institute, Queen Mary University of London, Barts and The London School of Medicine and Dentistry, London, UK. ${ }^{4}$ London School of Hygiene and Tropical Medicine, London, UK.

Received: 1 May 2012 Accepted: 17 August 2012

Published: 17 August 2012

\section{References}

1. Ballestar E: Epigenetics Lessons from Twins: Prospects for Autoimmune Disease. Clinical Reviews in Allergy \& Immunology 2010, 39(1):30-41.

2. Petronis $A$, Wong AHC, Gottesman II: Phenotypic differences in genetically identical organisms: the epigenetic perspective. Human Molecular Genetics 2005, 14:R11-R18.

3. Petronis $A$ : Epigenetics as a unifying principle in the aetiology of complex traits and diseases. Nature 2010, 465(7299):721-727.

4. Schinzel AAGL, Smith DW, Miller JR: Monozygotic Twinning and Structural Defects. Journal of Pediatrics 1979, 95(6):921-930.

5. Machin G: Non-identical Monozygotic Twins, Intermediate Twin Types, Zygosity Testing, and the Non-Random Nature of Monozygotic
Twinning. American Journal of Medical Genetics Part C-Seminars in Medical Genetics 2009, 151C(2):110-127.

6. Gardiner HM, Karatza AA, Wolfenden JL, Taylor MJO, Wee L, Fisk NM: Influence of twin-twin transfusion syndrome on fetal cardiovascular structure and function: prospective case-control study of 136 monochorionic twin pregnancies. Heart 2002, 88(3):271-277.

7. Mari G, Roberts A, Detti L, Kovanci E, Stefos T, Babado-Singh RO, Deter RL, Fisk NM: Perinatal morbidity and mortality rates in severe twin-twin transfusion syndrome: Results of the International Amnioreduction Registry. American Journal of Obstetrics and Gynecology 2001, 185(3):708-715.

8. Singh S, Murphy B, O'Reilly R: Epigenetic contributors to the discordance of monozygotic twins. Clinical Genetics 2002, 62(2):97-103.

9. Szymanski SaM, Malinowski Witold: Analysis of monochorionic and dichorionic twin pregnancies. Archives of Perinatal Medicine 2010, 16(2):4.

10. Dube J, Dodds L, Armson BA: Does chorionicity or zygosity predict adverse perinatal outcomes in twins? American Journal of Obstetrics and Gynecology 2002, 186(3):579-583.

11. Poulsen P, Levin K, Beck-Nielsen H, Vaag A: Age-dependent impact of zygosity and birth weight on insulin secretion and insulin action in twins. Diabetologia 2002, 45(12):1649-1657.

12. Spellacy WN, Handler A, Ferre CD: A Case-Control Study of 1253 Twin Pregnancies from a 1982-1987 Perinatal Data-Base. Obstetrics and Gynecology 1990, 75(2):168-171

13. Bajoria R, Kingdom J: The case for routine determination of chorionicity and zygosity in multiple pregnancy. Prenatal Diagnosis 1997, 17(13):1207-25.

14. Ramosarroyo MA, Ulbright TM, Yu PL, Christian JC: Twin Study Relationship between Birth-Weight, Zygosity, Placentation, and Pathologic Placental Changes. Acta Geneticae Medicae Et Gemellologiae 1988, 37(3-4):229-238.

15. Hoskins RE: Zygosity as a Risk Factor for Complications and Outcomes of Twin Pregnancy. American Journal of Epidemiology 1993, 138(8):657-658.

16. Braun MM, Ahlbom A, Floderus B, Brinton LA, Hoover RN: Effect of Twinship on Incidence of Cancer of the Testis, Breast, and Other Sites (Sweden). Cancer Causes \& Control 1995, 6(6):519-524.

17. Korsten P, Clutton-Brock T, Pilkington JG, Pemberton JM, Kruuk LEB: Sexual conflict in twins: male co-twins reduce fitness of female Soay sheep. Biology Letters 2009, 5(5):663-666.

18. Bajoria R, Sooranna SR, Ward S, D'Souza S, Hancock M: Placental transport rather than maternal concentration of amino acids regulates fetal growth in monochorionic twins: Implications for fetal origin hypothesis. American Journal of Obstetrics and Gynecology 2001, 185(5):1239-1246.

19. Quintero RA, Russell Z, Kontopoulos EV: Intrauterine growth restriction in monochorionic twins. Seminars in Fetal \& Neonatal Medicine 2007. 12(6):439-449

20. Bagchi S, Salihu HM: Birth weight discordance in multiple gestations: occurrence and outcomes. Journal of obstetrics and gynaecology: the journal of the Institute of Obstetrics and Gynaecology 2006, 26(4):291-6.

21. Victoria A, Mora G, Arias F: Perinatal outcome, placental pathology, and severity of discordance in monochorionic and dichorionic twins. Obstetrics and Gynecology 2001, 97(2):310-5.

22. Gringras $P, C$ Chen $W$ : Mechanisms for differences in monozygous twins. Early human development 2001, 64(2):105-17.

23. Demissie K, Ananth CV, Martin J, Hanley ML, MacDorman MF, Rhoads GG: Fetal and neonatal mortality among twin gestations in the United States: The role of intrapair birth weight discordance. Obstetrics and Gynecology 2002, 100(3):474-480.

24. Acosta-Rojas R, Becker J, Munoz-Abellana B, Ruiz C, Carreras E, Gratacos E: Twin chorionicity and the risk of adverse perinatal outcome. International Journal of Gynecology \& Obstetrics 2007, 96(2):98-102.

25. Wong HS, Kidd A, Zuccollo J, Parker S, Richardson V, Tait J, Pringle KC: A Case of Amyoplasia in a Monochorionic Twin Pregnancy: A Sequela from Twin-Twin Transfusion Syndrome? Fetal Diagnosis and Therapy 2009, 25(1):31-35.

26. Norris AW, Wang $C L$, Yao JR, Walsh $S A$, Sawatzke $A B$, Hu SM, Sunderland JJ, Segar JL, Ponto LLB: Effect of Insulin and Dexamethasone on Fetal Assimilation of Maternal Glucose. Endocrinology 2011, 152(1):255-262.

27. Petronis A, Ptak C: Epigenetics and complex disease: From etiology to new therapeutics. Annual Review of Pharmacology and Toxicology 2008, 48:257-276. 
28. Boomsma D, Busjahn A, Peltonen L: Classical twin studies and beyond. Nature Reviews Genetics 2002, 3(11):872-882.

29. Fraga MF, Ballestar E, Paz MF, Ropero S, Setien F, Ballestar ML, Heine-Suner D, Cigudosa JC, Urioste M, Benitez J, Boix-Chornet M, Sanchez-Aguilera A, Ling C, Carlsson E, Poulsen P, Vaag A, Stephan Z, Spector TD, Wu YZ, Plass C, Esteller M: Epigenetic differences arise during the lifetime of monozygotic twins. Proceedings of the National Academy of Sciences of the United States of America 2005, 102(30):10604-10609.

30. Bouchard TJ, Lykken DT, Mcque M, Segal NL, Tellegen A: Sources of Human Psychological Differences - the Minnesota Study of Twins Reared Apart. Science 1990, 250(4978):223-228.

31. Bouchard TJ, McGue M: Genetic and environmental influences on human psychological differences. Journal of Neurobiology 2003, 54(1):4-45.

32. Mastroeni D, McKee A, Grover A, Rogers J, Coleman PD: Epigenetic Differences in Cortical Neurons from a Pair of Monozygotic Twins Discordant for Alzheimer's Disease. Plos One 2009, 4(8).

33. Hirschhorn R: In vivo reversion to normal of inherited mutations in humans. Journal of Medical Genetics 2003, 40(10):721-728.

34. Bruder CEG, Piotrowski A, Gijsbers AACJ, Andersson R, Erickson S, de Stahl TD, Menzel U, Sandgren J, von Tell D, Poplawski A, Crowley M, Crasto C, Partridge EC, Tiwari H, Allison DB, Kornorowski J, van Ommen GJB, Boomsma DI, Pedersen NL, den Dunnen JT, Wirdefeldt K, Dumanski JP: Phenotypically concordant and discordant monozygotic twins display different DNA copy-number-variation profiles. American Journal of Human Genetics 2008, 82(3):763-771.

35. Frank SA: Somatic evolutionary genomics: Mutations during development cause highly variable genetic mosaicism with risk of cancer and neurodegeneration. Proceedings of the National Academy of Sciences of the United States of America 2010, 107:1725-1730.

36. Dumanski JP, Piotrowski A, Bruder CEG, Andersson R, de Stahl TD, Menzel U, Sandgren J, Poplawski A, von Tell D, Crasto C, Bogdan A, Bartoszewski R, Bebok Z, Krzyzanowski M, Jankowski Z, Partridge EC, Komorowski J: Somatic mosaicism for copy number variation in differentiated human tissues. Human Mutation 2008, 29(9):1118-1124.

37. Youssoufian H, Pyeritz RE: Mechanisms and consequences of somatic mosaicism in humans. Nature Reviews Genetics 2002, 3(10):748-758.

38. Gollob MH, Jones DL, Krahn AD, Danis L, Gong XQ, Shao Q, Liu XQ, Veinot JP, Tang ASL, Stewart AFR, Tesson F, Klein GJ, Yee R, Skanes AC, Guiraudon GM, Ebihara L, Bai D: Somatic mutations in the connexin 40 gene (GJA5) in atrial fibrillation. New England Journal of Medicine 2006, 354(25):2677-2688.

39. Erickson RP: Somatic gene mutation and human disease other than cancer. Mutation Research-Reviews in Mutation Research 2003, 543(2):125-136.

40. Erickson RP: Somatic gene mutation and human disease other than cancer: An update. Mutation Research-Reviews in Mutation Research 2010, 705(2):96-106.

41. Kinzler KW, Vogelstein B: Lessons from hereditary colorectal cancer. Cell 1996, 87(2):159-170.

42. Chang AEaM, AM : Colorectal Cancer. In Greenfield's Surgery M.L Edited by: Mulholland KD, Doherty GM, Maier RV, Upchurch GR 2006, 1103-1129.

43. Pogribny IP, Beland FA: DNA hypomethylation in the origin and pathogenesis of human diseases. Cellular and molecular life sciences: CMLS 2009, 66(14):2249-61.

44. Hoffmann MJ, Schulz WA: Causes and consequences of DNA hypomethylation in human cancer. Biochemistry and cell biology = Biochimie et biologie cellulaire 2005, 83(3):296-321.

45. A map of human genome variation from population-scale sequencing. Nature 2010, 467(7319):1061-73.

46. Shotelersuk V, Tifft CJ, Vacha S, Peters KF, Biesecker LG: Discordance of oral-facial-digital syndrome type 1 in monozygotic twin girls. American journal of medical genetics 1999, 86(3):269-73.

47. Kato T, Iwamoto K, Kakiuchi C, Kuratomi G, Okazaki Y: Genetic or epigenetic difference causing discordance between monozygotic twins as a clue to molecular basis of mental disorders. Molecular psychiatry 2005, 10(7):622-30.

48. Kaplan L, Foster R, Shen Y, Parry DM, McMaster ML, O'Leary MC, Gusella JF: Monozygotic twins discordant for neurofibromatosis 1 . American journal of medical genetics Part A 2010, 152A(3):601-6.

49. Gottlieb B, Beitel LK, Trifiro MA: Somatic mosaicism and variable expressivity. Trends in genetics: TIG 2001, 17(2):79-82.
50. Raynes HR, Shanske A, Goldberg S, Burde R, Rapin I: Joubert syndrome: monozygotic twins with discordant phenotypes. Journal of child neurology 1999, 14(10):649-54, discussion 669-72 discussio.

51. Yamagishi H, Ishii C, Maeda J, Kojima Y, Matsuoka R, Kimura M, Takao A, Momma K, Matsuo N: Phenotypic discordance in monozygotic twins with 22q11.2 deletion. American journal of medical genetics 1998, 78(4):319-21.

52. Itsara A, Wu H, Smith JD, Nickerson DA, Romieu I, London SJ, Eichler EE: De novo rates and selection of large copy number variation. Genome research 2010, 20(11):1469-81.

53. Notini AJ, Craig JM, White SJ: Copy number variation and mosaicism. Cytogenetic and genome research 2008, 123(1-4):270-7.

54. Imamura A, Ono S, Tasaki S, Kurotaki N, Ozawa H, Yoshiura K, Okazaki Y: Failure to Confirm CNVs as of Aetiological Significance in Twin Pairs Discordant for Schizophrenia. Twin Research and Human Genetics 2010, 13(5):455-460.

55. Grayson BL, Smith ME, Thomas JW, Wang L, Dexheimer P, Jeffrey J, Fain PR, Nanduri P, Eisenbarth GS, Aune TM: Genome-Wide Analysis of Copy Number Variation in Type 1 Diabetes. Plos One 2010, 5(11).

56. Baiget M, Lasa A, Cajal TRY, Llort G, Suela J, Cigudosa JC, Cornet M, Alonso C, Barnadas A: Copy number variations are not modifiers of phenotypic expression in a pair of identical twins carrying a BRCA1 mutation. Breast Cancer Research and Treatment 2010, 123(3):901-905.

57. Whitelaw E, Blewitt ME, Chong S: How the mouse got its spots. Trends in Genetics 2004, 20(11):550-554.

58. Forde BG: Is it good noise? The role of developmental instability in the shaping of a root system. Journal of Experimental Botany 2009, 60(14):3989-4002.

59. Losick R, Desplan C: Stochasticity and cell fate. Science 2008, 320(5872):65-68.

60. Zernicka-Goetz M, Huang S: Stochasticity versus determinism in development: a false dichotomy? Nature Reviews Genetics 2010, 11(11):743-744.

61. van Oudenaarden A, Raj A, Rifkin SA, Andersen E: Variability in gene expression underlies incomplete penetrance. Nature 2010, 463(7283):913-U84.

62. Desplan C, Johnston RJ: A Penetrating Look at Stochasticity in Development. Cell 2010, 140(5):610-612.

63. Kaern M, Elston TC, Blake WJ, Collins JJ: Stochasticity in gene expression: From theories to phenotypes. Nature Reviews Genetics 2005, 6(6):451-464.

64. Petronis A: Epigenetics and twins: three variations on the theme. Trends in Genetics 2006, 22(7):347-350.

65. Stamatoyannopoulos JA: The genomics of gene expression. Genomics 2004, 84(3):449-457.

66. Vassart G, Dumont JE: Thyroid dysgenesis: Multigenic or epigenetic... or both? Endocrinology 2005, 146(12):5035-5037.

67. Wang JH, Valo Z, Bowers CW, Smith DD, Liu Z, Singer-Sam J: Dual DNA Methylation Patterns in the CNS Reveal Developmentally Poised Chromatin and Monoallelic Expression of Critical Genes. Plos One 2010, $5(11)$

68. Lee MP, Lo HS, Wang ZN, Hu Y, Yang HH, Gere S, Buetow KH: Allelic variation in gene expression is common in the human genome. Genome research 2003, 13(8): 1855-1862.

69. Singer-Sam J, Wang JH, Valo Z, Smith D: Monoallelic Expression of Multiple Genes in the CNS. Plos One 2007, 2(12).

70. Chess A, Gimelbrant A, Hutchinson JN, Thompson BR: Widespread monoallelic expression on human autosomes. Science 2007, 318(5853):1136-1140.

71. Spielman RS, Cheung VG, Bruzel A, Burdick JT, Morley M, Devlin JL: Monozygotic twins reveal germline contribution to allelic expression differences. American Journal of Human Genetics 2008, 82(6):1357-1360.

72. Baranzini SE, Mudge J, van Velkinburgh JC, Khankhanian P, Khrebtukova I, Miller NA, Zhang L, Farmer AD, Bell CJ, Kim RW, May GD, Woodward JE, Caillier SJ, McElroy JP, Gomez R, Pando MJ, Clendenen LE, Ganusova EE, Schilkey FD, Ramaraj T, Khan OA, Huntley JJ, Luo SJ, Kwok P, Wu TD, Schroth GP, Oksenberg JR, Hauser SL, Kingsmore SF: Genome, epigenome and RNA sequences of monozygotic twins discordant for multiple sclerosis. Nature 2010, 464(7293):1351-U6.

73. Jaenisch R, Bird A: Epigenetic regulation of gene expression: how the genome integrates intrinsic and environmental signals. Nature Genetics 2003, 33:245-254. 
74. Youngson NA, Whitelaw E: Transgenerational epigenetic effects. Annual Review of Genomics and Human Genetics 2008, 9:233-257.

75. Jiang YH, Bressler J, Beaudet AL: Epigenetics and human disease. Annual Review of Genomics and Human Genetics 2004, 5:479-510.

76. Watson JD: Molecular biology of the gene. San Francisco Cold Spring Harbor, N.Y.: Pearson/Benjamin Cummings. 6 edition. Cold Spring Harbor Laboratory Press; 2008, 841, xxxii.

77. Whitelaw E, Daxinger L: Transgenerational epigenetic inheritance: More questions than answers. Genome research 2010, 20(12):1623-1628.

78. Ecker JR, Lister R, Pelizzola M, Dowen RH, Hawkins RD, Hon G, TontiFilippini J, Nery JR, Lee L, Ye Z, Ngo QM, Edsall L, Antosiewicz-Bourget J, Stewart R, Ruotti V, Millar AH, Thomson JA, Ren B: Human DNA methylomes at base resolution show widespread epigenomic differences. Nature 2009, 462(7271):315-322.

79. Peinado MA, Frigola J, Ribas M, Risques RA: Methylome profiling of cancer cells by amplification of inter-methylated sites (AIMS). Nucleic Acids Research 2002, 30(7).

80. Rakyan VK, Finer S, Holland ML, Nanty L: The Hunt for the Epiallele. Environmental and Molecular Mutagenesis 2011, 52(1):1-11.

81. Gartner K: A third component causing random variability beside environment and genotype. A reason for the limited success of a 30 year long effort to standardize laboratory animals? Laboratory animals 1990, 24(1):71-7.

82. Galetzka D, Hansmann T, El Hajj N, Weis E, Irmscher B, Ludwig M, Schneider-Ratzke B, Kohlschmidt N, Beyer V, Bartsch O, Zechner U, Spix C, Haaf T: Monozygotic twins discordant for constitutive BRCA1 promoter methylation, childhood cancer and secondary cancer. Epigenetics 2012, 7(1):47-54.

83. Weksberg R, Shuman C, Caluseriu O, Smith AC, Fei YL, Nishikawa J, Stockley TL, Best L, Chitayat D, Olney A, Ives E, Schneider A, Bestor TH, Li M, Sadowski P, Squire J: Discordant KCNQ10T1 imprinting in sets of monozygotic twins discordant for Beckwith-Wiedemann syndrome. Human Molecular Genetics 2002, 11(11):1317-1325.

84. Martin GM: Epigenetic drift in aging identical twins. Proceedings of the National Academy of Sciences of the United States of America 2005, 102(30):10413-10414

85. Kaminsky ZA, Tang T, Wang SC, Ptak C, Oh GHT, Wong AHC, Feldcamp LA Virtanen C, Halfvarson J, Tysk C, McRae AF, Visscher PM, Montgomery GW, Gottesman II, Martin NG, Petronis A: DNA methylation profiles in monozygotic and dizygotic twins. Nature Genetics 2009, 41(2):240-245.

86. Saffery $\mathrm{R}$, Ollikainen $\mathrm{M}$, Smith $\mathrm{KR}$, Joo EJH, Ng HK, Andronikos $\mathrm{R}$, Novakovic B, Aziz NKA, Carlin JB, Morley R, Craig JM: DNA methylation analysis of multiple tissues from newborn twins reveals both genetic and intrauterine components to variation in the human neonatal epigenome. Human Molecular Genetics 2010, 19(21):4176-4188.

87. Wong CCY, Caspi A, Williams B, Craig IW, Houts R, Ambler A, Moffitt TE, Mill J: A longitudinal study of epigenetic variation in twins. Epigenetics 2010, 5(6)

88. Talens RP, Christensen K, Putter H, Willemsen G, Christiansen L, Kremer D, Suchiman HE, Slagboom PE, Boomsma DI, Heijmans BT: Epigenetic variation during the adult lifespan: cross-sectional and longitudinal data on monozygotic twin pairs. Aging Cell

89. Boks MP, Derks EM, Weisenberger DJ, Strengman E, Janson E, Sommer IE, Kahn RS, Ophoff RA: The Relationship of DNA Methylation with Age, Gender and Genotype in Twins and Healthy Controls. Plos One 2009, $4(8)$.

90. Rakyan VK, Down TA, Maslau S, Andrew T, Yang TP, Beyan H, Whittaker P, McCann OT, Finer S, Valdes AM, Leslie RD, Deloukas P, Spector TD: Human aging-associated DNA hypermethylation occurs preferentially at bivalent chromatin domains. Genome research 2010, 20(4):434-439.

91. Petronis A, Gottesman IL, Kan PX, Kennedy JL, Basile VS, Paterson AD, Popendikyte $\mathrm{V}$ : Monozygotic twins exhibit numerous epigenetic differences: Clues to twin discordance? Schizophrenia Bulletin 2003, 29(1):169-178.

92. Mill J, Dempster E, Caspi A, Williams B, Moffitt T, Craig I: Evidence for monozygotic twin (MZ) discordance in methylation level at two CpG sites in the promoter region of the catechol-O-methyltransferase (COMT) gene. American Journal of Medical Genetics Part B-Neuropsychiatric Genetics 2006, 141B(4):421-425

93. Oates NA, van Vliet J, Duffy DL, Kroes HY, Martin NG, Boomsma DI, Campbell M, Coulthard MG, Chong S, Whitelaw E: Increased DNA methylation at the AXIN1 gene in a monozygotic twin from a pair discordant for a caudal duplication anomaly. American Journal of Human Genetics 2006, 79(1):155-162.

94. Kaminsky Z, Petronis A, Wang SC, Levine B, Ghaffar O, Floden D, Feinstein A: Epigenetics of personality traits: An illustrative study of identical twins discordant for risk-taking behavior. Twin Research and Human Genetics 2008, 11(1):1-11.

95. Kuratomi G, Iwamoto K, Bundo M, Kusumi I, Kato N, Iwata N, Ozaki N, Kato T: Aberrant DNA methylation associated with bipolar disorder identified from discordant monozygotic twins. Molecular psychiatry 2008 13(4):429-441

96. Javierre BM, Fernandez AF, Richter J, Al-Shahrour F, Martin-Subero J, Rodriguez-Ubreva J, Berdasco M, Fraga MF, O'Hanlon TP, Rider LG, Jacinto FV, Lopez-Longo FJ, Dopazo J, Forn M, Peinado MA, Carreno L, Sawalha AH, Harley JB, Siebert R, Esteller M, Miller FW, Ballestar E: Changes in the pattern of DNA methylation associate with twin discordance in systemic lupus erythematosus. Genome research 2010, 20(2):170-179.

97. Bell JT, Spector TD: A twin approach to unraveling epigenetics. Trends in Genetics 2011, 27(3):116-125.

98. Hu W, Nguyen A, Rauch TA, Pfeifer GP: Global methylation profiling of lymphoblastoid cell lines reveals epigenetic contributions to autism spectrum disorders and a novel autism candidate gene, RORA, whose protein product is reduced in autistic brain. Faseb Journal 2010, 24(8):3036-3051

99. Dempster EL, Pidsley R, Schalkwyk LC, Owens S, Georgiades A, Kane F, Kalidindi S, Picchioni M, Kravariti E, Toulopoulou T, Murray RM, Mill J: Disease-associated epigenetic changes in monozygotic twins discordant for schizophrenia and bipolar disorder. Human Molecular Genetics 2011, 20(24):4786-4796.

100. Gervin K, Vigeland MD, Mattingsdal M, Hammero M, Nygard H, Olsen AO, Brandt I, Harris JR, Undlien DE, Lyle R: DNA Methylation and Gene Expression Changes in Monozygotic Twins Discordant for Psoriasis: Identification of Epigenetically Dysregulated Genes. Plos Genetics 2012, $8(1)$.

101. Heijmans BT, Mill J: Commentary: The seven plagues of epigenetic epidemiology. Int J Epidemio/ 41(1):74-8.

102. Bell JT, Saffery R: The value of twins in epigenetic epidemiology. Int J Epidemio/ 41(1):140-50

103. Hirschhorn JN, Altshuler D: Editorial: Once and again - Issues surrounding replication in genetic association studies. Journal of Clinical Endocrinology \& Metabolism 2002, 87(10):4438-4441.

104. Hirschhorn JN, Daly MJ: Genome-wide association studies for common diseases and complex traits. Nature Reviews Genetics 2005, 6(2):95-108.

105. Dichgans M, Markus HS: Genetic association studies in stroke methodological issues and proposed standard criteria. Stroke 2005, 36(9):2027-2031

106. Tan NCK, Mulley JC, Berkovic SF: Genetic association studies in epilepsy: "The truth is out there". Epilepsia 2004, 45(11):1429-1442.

107. McCarthy MI, Abecasis GR, Cardon LR, Goldstein DB, Little J, loannidis JPA, Hirschhorn JN: Genome-wide association studies for complex traits: consensus, uncertainty and challenges. Nature Reviews Genetics 2008 9(5):356-369.

108. Daly MJ, Péer I, de Bakker PIW, Maller J, Yelensky R, Altshuler D: Evaluating and improving power in whole-genome association studies using fixed marker sets. Nature Genetics 2006, 38(6):663-667.

109. Porteous D: Genetic causality in schizophrenia and bipolar disorder: out with the old and in with the new. Current Opinion in Genetics \& Development 2008, 18(3):229-234.

110. Cox DR: Causality - Some Statistical Aspects. Journal of the Royal Statistical Society Series a-Statistics in Society 1992, 155:291-301.

111. Freedman D: From association to causation via regression. Advances in Applied Mathematics 1997, 18(1):59-110.

112. Freedman D: From association to causation: Some remarks on the history of statistics. Statistical Science 1999, 14(3):243-258.

113. Agbabiaka TB, Savovic J, Ernst E: Methods for causality assessment of adverse drug reactions - A systematic review. Drug Safety 2008, 31(1):21-37.

114. Donnelly P: Progress and challenges in genome-wide association studies in humans. Nature 2008, 456(7223):728-731.

115. Rakyan VK, Down TA, Balding DJ, Beck S: Epigenome-wide association studies for common human diseases. Nature Reviews Genetics 2011, 12(8):529-541. 
116. Rakyan VK, Beyan H, Down TA, Hawa MI, Maslau S, Aden D, Daunay A, Busato F, Mein CA, Manfras B, Dias KR, Bell CG, Tost J, Boehm BO, Beck S, Leslie RD: Identification of type 1 diabetes-associated DNA methylation variable positions that precede disease diagnosis. PLoS Genet 7(9): e1002300.

117. Haque FN, Gottesman II, Wong AH: Not really identical: epigenetic differences in monozygotic twins and implications for twin studies in psychiatry. American journal of medical genetics. Part C, Seminars in medical genetics 2009, 151C(2):136-41

118. Tierling S, Souren NY, Reither S, Zang KD, Meng-Hentschel J, Leitner D, Oehl-Jaschkowitz B, Walter J: DNA methylation studies on imprinted loci in a male monozygotic twin pair discordant for Beckwith-Wiedemann syndrome. Clinical Genetics 2011, 79(6):546-553.

119. Harder A, Titze S, Herbst L, Harder T, Guse K, Tinschert S, Kaufmann D, Rosenbaum T, Mautner VF, Windt E, Wahllander-Danek U, Wimmer K, Mundlos S, Peters H: Monozygotic twins with neurofibromatosis type 1 (NF1) display differences in methylation of NF1 gene promoter elements, $5^{\prime}$ untranslated region, exon and intron 1 . Twin research and human genetics: the official journal of the International Society for Twin Studies 2010, 13(6):582-94.

120. Souren NY, Tierling S, Fryns JP, Derom C, Walter J, Zeegers MP: DNA methylation variability at growth-related imprints does not contribute to overweight in monozygotic twins discordant for BMI. Obesity 2011, 19(7):1519-22.

\section{Pre-publication history}

The pre-publication history for this paper can be accessed here: http://www.biomedcentral.com/1741-7015/10/93/prepub

doi:10.1186/1741-7015-10-93

Cite this article as: Czyz et al:: Genetic, environmental and stochastic factors in monozygotic twin discordance with a focus on epigenetic differences. BMC Medicine 2012 10:93.

\section{Submit your next manuscript to BioMed Central and take full advantage of:}

- Convenient online submission

- Thorough peer review

- No space constraints or color figure charges

- Immediate publication on acceptance

- Inclusion in PubMed, CAS, Scopus and Google Scholar

- Research which is freely available for redistribution

Submit your manuscript at www.biomedcentral.com/submit 